\title{
Post-lesbian? Gendering Queer Performance Research
}

\author{
SARAH MULLAN
}

'Queer' and 'lesbian' are terms that offer valuable interventions in the field of theatre and performance studies. Current scholarship largely does not account for an amalgamation of these two positions, but, as some female performers, such as Rosana Cade, are aligning their work with both terms, there is a need for a more nuanced discourse that accounts for an engagement with the histories ascribed to 'queer' and 'lesbian' in performance and what these terms offer. My doctoral research seeks to investigate whether the term 'post-lesbian' is beneficial for analysing contemporary practice that draws from both positions.

The recent work of 'out' performer Rosana Cade foregrounds her sexuality in the publicity material for her shows: the advertising for My Big Sister Taught Me This Lapdance (2013) and Sisters (2013) proclaims, 'I am a lesbian with a shaved head and a hairy body' and 'Rosana is a lesbian with a shaved head and hairy arm-pits'. ${ }^{1}$ Yet Cade asserts that her performances are rooted in 'queer discourse'. ${ }^{2}$ While Cade's identification of her work situates it within a larger queer dialogue, the advertising indicates a desire to acknowledge the particularity of 'lesbian' identity. The choice to utilize both terms, despite 'queer' supposedly encompassing 'lesbian', suggests that this is a necessary collision.

It is imperative to recognize that 'lesbian' and 'queer' offer distinctive interventions to different audiences, yet they also contain a semantic weight. Such weight derives from each term's accumulated histories; it is worth, then, briefly historicizing 'lesbian' and 'queer' in order to illustrate their political efficacies and the limitations of both when analysing performance work that draws from the two positions. The term 'lesbian' is firmly rooted in an identity politics often seen to pre-date, and consequently to be outmoded by, the term 'queer'; it is a mode of political thinking that assumes that identity can bridge the gap between the personal and the political. An argument for 'lesbian' is that a determined focus on one aspect of identity can prove valuable by increasing the visibility of a minority. Nevertheless, identity politics is frequently critiqued for reproducing essentialist categories and for regulating identity formations. Lesbian identity politics has a particularly contentious history given its association with the lesbian-feminist split of the 1970s, the subsequent lesbian separatism movement and the notion of political lesbianism. ${ }^{3}$ Such historical fractures of the lesbian/lesbian feminist movement have rendered 'lesbian' a 'sticky sign' (to borrow Sara Ahmed's concept) through its accumulated histories and associations. ${ }^{4}$

In contrast, queer derives from the proposition that all identity is constructed. One of the strengths of 'queer' is that it is a non-gender-specific umbrella term incorporating a diverse range of 'non-normative' positions that include gay, lesbian, transgender and 
bisexual. In particular, this aspect of 'queer' has been used vernacularly to provide political solidarity outside identity categories, for example in the case of the activist group Queer Nation. Although 'lesbian' is incorporated within the overarching aims of queer thinking, 'queer' largely does not account for the specificity of a lesbian identity, a specificity that is located in gender. Suzanna Danuta Walters challenges the 'unproblematized' merging of gay men and lesbian experiences as if they are synonymous and asserts that the implicit referent in queer discourse is 'a universal gay male subject'. ${ }^{5}$ A significant weakness with 'queer', then, is that its gender-neutrality can be interpreted as gender-dismissive.

Returning to the example of Cade's work, the current rhetoric does not account for a reluctance to identify solely as queer that is paired with a parallel resistance to the semantically burdened label 'lesbian'. Lesbian performance theory, which predominated in the pre-queer 1980 os and early 1990s, is insufficient for fully analysing this collision. ${ }^{6}$ The key concerns within lesbian performance scholarship revolve around the desire to represent a 'lesbian' subject, whereas the conceptual developments within queer theory would instead suggest that a reflexive questioning of the role of identitybased 'lesbian' performance should be a key concern. Although this work could be critically discussed through either a 'queer' or a 'lesbian' paradigm, to privilege one would be to disavow Cade's inclusion of the other. How can female performers who seek to engage with aspects of these terms, and strategically utilize both, be critically discussed?

There is, then, a need for a new paradigm that can deal with the specificity of lesbian within a queer framework. It is essential for queer researchers to turn their attention to these instances of nuanced performance and begin to construct a critical dialogue. This is particularly pertinent as female work is currently vastly underrepresented within queer scholarship and performance. The increasing addition of modifiers to queer, in terms such as queer femme and genderqueer, further suggests that it is inadequate in accounting for the specificity of gender. The work of Elizabeth Freeman, however, has been particularly reparative in its reclamation of 'lesbian' within a post-structuralist world view. ${ }^{7}$ New terminology might also work towards offering a corrective by drawing attention to, and focusing on, lesbian/queer women's performance and actively destabilizing the dominant gay male referent. A term such as 'post-lesbian' performance, for instance, could prove beneficial for marking a distinction between, on the one hand, 'lesbian' and 'queer' performances and, on the other, those that utilize a hybrid of queer epistemologies and lesbian representation. The term has been discussed within lesbian studies, but it is not currently in circulation within performance studies. ${ }^{8}$ One of the most productive conceptions is Bonnie Zimmerman's positing that perhaps a 'post-lesbianism to go along with a postfeminism' is necessary in order to develop lesbian studies further. ${ }^{9}$ This conception of 'post-lesbianism' situates the term alongside other 'posts', such as 'post-feminism' and 'postmodernism', as a position that seeks to renegotiate 'lesbian' and the set of embodied practices that the term suggests. Just as 'post-feminism' does not discard feminism and 'postmodernism' does not disregard 'modernism', 'post-lesbian' does not disavow the identity category of lesbian, but accounts for the influence of queer and post-structuralist thought. 
Drawing from materialist and intersectional analyses in order to avoid essentialism, 'post-lesbian performance' is a term that could be useful in analysing work that foregrounds lesbian identity, yet makes use of queer performance strategies and epistemologies in order to destabilize what 'lesbian' actually means. This new terminology may also prove to be less restrictive than 'lesbian' performance, as it could incorporate performances that do not explicitly self-define as 'lesbian' yet foreground same-sex female desire or eroticism. 'Post-lesbian', then, may provide an opportunity to amalgamate the benefits of the existing terminology while also compensating for its limitations. While 'post' accounts for the post-structuralist assertion that all identity is constructed, the foregrounding of 'lesbian' in this term (rather than 'queer') is a political move that draws attention to, and refuses to dismiss, gendered experience, with all of its 'lived' effects. Thus it potentially offers a constructive intersection in the histories of both 'lesbian' and 'queer'.

Judith Butler has articulated the difficulty of both rejecting 'lesbian' subjectivity and also desiring to engage with it, proclaiming that 'I would like to have it permanently unclear what precisely that sign [lesbian] signifies'. ${ }^{10}$ I would posit that a growing body of performance work, such as Cade's, attempts to take up Butler's desire to evoke potential 'futural significations' for the sign of 'lesbian'. ${ }^{11}$ New terminology may offer one way to acknowledge this queering of 'lesbian', given the history of each term, or the strategic deployment of 'lesbian' or 'lesbian/queer' by performers may negate the need for wholly new terminology. Whichever mode(s) this manifests in, the current eclipsing of gender within queer theatre and performance discourse warrants further attention and consideration from queer scholars in the field.

NOTES

1 Rosana Cade, My Big Sister Taught Me This Lapdance, at http://rosanacadedotcom.wordpress.com/ my-big-sister-taught-me-this-lapdance, last accessed 7 April 2014; 'Amy and Rosana Cade', Battersea Arts Centre, at www.bac.org.uk/content/30125/about_us/past_shows/sister_preview, last accessed 7 April 2014.

2 Rosana Cade, at http://rosanacadedotcom.wordpress.com, last accessed 7 April 2014.

3 Carolyn Dever, 'Obstructive Behaviour: Dykes in the Mainstream of Feminist Theory', in Dana Heller, ed., Cross Purposes: Lesbians, Feminists, and the Limits of Alliance (Bloomington: Indiana University Press, 1997), pp. 19-42.

4 Sara Ahmed, The Cultural Politics of Emotion (New York: Routledge, 2007), p. 91.

5 Suzanna Danuta Walters, 'From Here to Queer: Radical Feminism, Postmodernism, and the Lesbian Menace', Signs, 21, 4 (Summer 1996), pp. 830-69, here p. 845.

6 Notable examples of lesbian performance theory are Kate Davy, 'Constructing the Spectator: Reception, Context, and Address in Lesbian Performance', Performing Arts Journal, 10, 2 (1986), pp. 43-52; Nina Rapi, 'Hide and Seek: The Search for a Lesbian Theatre Aesthetic', New Theatre Quarterly, 9 (1993), pp. 147-58.

7 Elizabeth Freeman, Time Binds: Queer Temporalities, Queer Histories (Durham, NC and London: Duke University Press, 2010).

8 Charlotte Aston, 'Getting Hold of the Phallus: Post-lesbian Power Negotiations', in Nicola Goodwin, Belinda Hallows and Sheridan Nye, eds., Assaults on Convention: Essays on Lesbian Transgressors (London: Cassell, 1996), pp. 158-74; Toni McNaron, 'Post-lesbian? Not Yet', Journal of Lesbian Studies, special issue, 11, 1-2 (2007), pp. 145-51. 
9 Bonnie Zimmerman, 'Placing Lesbians', in Bonnie Zimmerman and Toni McNaron, eds., The New Lesbian Studies (New York: The Feminist Press, 1996) pp. 269-77, here p. 274. Judith Butler, 'Imitation and Gender Insubordination', in Henry Abelove, Michéle Barale and David Halperin, eds., The Lesbian and Gay Studies Reader (London: Routledge, 1993) pp. 307-20, here p. 308. Ibid., p. 312.

SARAH MULLAN (s.j.mullan@qmul.ac.uk) is a PhD Researcher and Teaching Associate in the Department of Drama at Queen Mary, University of London. Her PhD thesis considers the interplay between queer epistemologies and contemporary lesbian performance in London. She is the co-convenor of the IFTR/FIRT's Queer Futures working group. 